\title{
Factors determining milk quality and implications for production structure under somatic cell count standard modification
}

\author{
F. Dong, ${ }^{*}$ D. A. Hennessy, ${ }^{1}{ }^{1}$ and H. H. Jensen $\dagger$ \\ *Department of Agricultural and Applied Economics, University of Wisconsin-Madison 53706-1503 \\ †Center for Agricultural and Rural Development, Department of Economics, lowa State University, Ames 50011-1070
}

\begin{abstract}
Consumer and processor demand for high-quality milk has placed increasing pressure on US milk producers to achieve higher product standards. International standards for somatic cell count (SCC) are becoming more stringent, but in May 2011, the United States National Conference on Interstate Milk Shipments chose to retain the 750,000 cells $/ \mathrm{mL}$ standard. Using ordinary least squares and quantile regressions on US Department of Agriculture Agricultural Resource Management Survey Dairy Costs and Returns Report data for 2005, we model producer and farm-level characteristics associated with SCC. Quantile regression analysis allows for a more parsed inquiry into statistical associations. Dairy Costs and Returns Report data provide cross-sectional information on the physical structure, input expenses, demographics, and outputs for farms in selected states. Location outside the Southeast, lower herd age, full-time farming status, use of biosecurity guidelines, good milking facilities and operations management, and application of related quality tests are all associated with lower SCC levels. Size of operation had little effect on SCC levels after controlling for other factors. Many of the operations that did not attain a more demanding SCC standard of 400,000 cells/mL had older operators, operators who expressed intention to exit within $10 \mathrm{yr}$, smaller size, and location in the Southeast when compared with those meeting the tighter standard. The results suggest that the stricter scheme favors larger farms that are more committed to production and are less likely to be sole or family proprietorships.
\end{abstract}

Key words: dairy farm characteristics, international markets, production scale, somatic cell count

Received March 9, 2012

Accepted July 26, 2012.

${ }^{1}$ Corresponding author: hennessy@iastate.edu

\section{INTRODUCTION}

Consumer and processor demand in domestic and international markets for safe, high-quality dairy products has placed increasing pressure on US milk producers. Somatic cell count is 1 of 2 mandated measures for determining the quality of milk under the Grade "A" Pasteurized Milk Ordinance, the other being standard plate count (US Department of Health and Human Services, 2009). An uninfected udder will typically have SCC less than 100,000 cells/mL. Generally, a lower SCC indicates better animal health. High SCC milk reduces product quality and yield from processing activities (Stephenson and Barbano, 2010) as well as fluid milk shelf life (Barbano et al., 2006).

The grade "A" Pasteurized Milk Ordinance indicates that an individual producer's milk SCC should not exceed 750,000 cells/mL (US Department of Health and Human Services, 2009), a standard that has been in place since first implementation in 1993. The United States has the highest upper limit for SCC among the developed world's major dairy-producing countries (Norman et al., 2000; Smith and Hogan, 2001). The European Union (EU), New Zealand, Australia, Switzerland, and Norway have all accepted 400,000 cells/ $\mathrm{mL}$ as the upper limit. Canada sets the limit at 500,000 cells/mL, whereas Ontario lowered the limit to 400,000 cells/mL in August 2012. The high US SCC limits leaves it undesirably positioned in export markets, to some degree implying that US dairy products are of comparatively low quality (Smith and Hogan, 2001). However, some states have recently lowered their state limits and many dairy processors have already imposed stricter standards on their producers (Norman et al., 2011). For example, California changed its upper limit to 600,000 cells $/ \mathrm{mL}$ in 2009. In 2012, Oregon adopted a new state SCC limit of 500,000 cells/mL, whereas Idaho lowered its state standard to 400,000 cells $/ \mathrm{mL}$. Concerned about product shelf life and flavor, some US processors have begun to seek producers that can supply at or below 250,000 cells/mL (Schutz, 2011).

Accounting for about one-eighth of production, US dairy exports have displayed an increasing trend from 
the period 2000 to 2011 , with $\$ 4.82$ billion in exports and $\$ 2.4$ billion in trade surplus in 2011 (Jesse and Dobson, 2012). Export growth has been strongest to the rapidly growing economies of East Asia. Historical evidence suggests that quality standards are likely to increase eventually with the rise in per capita income (Caswell and Bach, 2007). If US dairy exporters are to remain competitive in these markets, then they will need to be competitive on the quality margin as well as the price margin.

The EU has taken steps toward tighter restrictions on SCC for milk imported by EU members. Prior to 2012, the EU had allowed US imports based on a pooled milk SCC at the plant or tank truck of less than 400,000 cells/mL. However, effective in 2012 EU regulations require the 3 -mo geometric mean for SCC to be no more than 400,000 cells $/ \mathrm{mL}$ on every farm that contributes to the pool for imported milk (Norman et al., 2011). Yet, within the US, Norman and colleagues (2011) found that 16.1\% of US herds delivering to 1 of 4 Federal Milk Marketing Orders were not in compliance with the EU SCC standard. United States exports to the EU accounted for around $2 \%$ of total US dairy exports in 2010 in both value and quantity. However, it is often cost inefficient to segregate milk collected from farms that do and do not attain a quality level because the destination for products is often not determined until shortly before shipment (Burggraff, 2010).

Recent proposals to reduce the maximum level of SCC in US milk to 400,000 cells/mL have been supported by many agencies and organizations, including the Secretary of Agriculture (Washington, DC), US Department of Agriculture (USDA) Dairy Industry Advisory Committee (Washington, DC), the National Milk Producers Federation (Arlington, VA), and the National Mastitis Council (Verona, WI; USDA, 2011). However, the proposed changes were not approved by a 25 to 26 vote at the National Conference on Interstate Milk Shipments (NCIMS) in May 2011 (Dickrell, 2011). A major concern was that the tighter standards would render many small and southern dairy farms unviable.

The objectives of this study are 2-fold. The first is to examine factors associated with SCC levels, including management and production practices and milk producer socioeconomic characteristics. Few empirical studies have investigated an extensive set of factors affecting SCC. Most studies to date have focused on a limited set of factors including SCC quality premium, cow age, season, lactation, supplementation, and participation in cow-level data collection programs (Salsberg et al., 1984; Nightingale et al., 2008; Gaafar et al., 2010; Dufour et al., 2011; Hand et al., 2012). We extend the set of factors related to SCC to identify factors that can help herd managers to understand the potential causes of higher SCC levels and thus take corresponding actions to improve milk quality.

The second objective is to understand implications of changes in SCC standards for the structure of the dairy industry - the concern expressed by NCIMS delegates in opposition to proposed changes in SCC standards. To this end, we use USDA Agricultural Resource Management Survey (ARMS) data to assess how tightened standards would affect farms in different regions.

\section{MATERIALS AND METHODS}

\section{Empirical Framework}

If every farm that contributes to a milk pool must meet a certain SCC standard, then it is critical to understand the nature of the weakest link, namely highSCC farms. Although ordinary least squares (OLS) regression can address the question "Is this factor important to SCC?" it cannot answer "Does this factor influence SCC differently for operations with high SCC than for those with average or low SCC?" Quantile regression enables an examination of associated factors at different SCC levels. Quantile regression is similar to OLS except that weighted absolute deviations are minimized so that the expectation is a quantile prediction (Koenker and Bassett, 1978). The approach allows for a more detailed inquiry into how the distribution of outcomes is shaped by a set of covariates. In addition, because quantile regression uses absolute deviations, it is more robust in response to large outliers.

As described by Koenker and Bassett (1978), the quantile regression model can be written as

$$
y_{i}=x_{i}^{\prime} \beta_{\theta}+u_{\theta, i} \text { with } \operatorname{Quant}_{\theta}\left(y_{i} \mid x_{i}\right)=x_{i}^{\prime} \beta_{\theta},
$$

where $\left(y_{i}, x_{i}\right), i \in\{1, \ldots, n\}$ is a sample from some population, $x_{i}$ is a $K \times 1$ vector of regressors, $\beta_{\theta}$ is the associated real valued parameter vector to be estimated at the $\theta$ th $(0<\theta<1)$ quantile, and $u_{\theta, i}$ is a vector of residuals that adheres to the quantile restriction Quant $_{\theta}\left(u_{\theta, i} \mid x_{i}\right)=0$ (Buchinsky, 1998), where Quant $_{\theta}\left(y_{i}\right.$ | $x_{i}$ ) denotes the $\theta$ th conditional quantile of $y_{i}$ given $x_{i}$. The $\theta$ th regression quantile is defined as any solution to the minimization problem:

$$
\begin{aligned}
\hat{\beta}_{\theta}= & \arg \min _{\beta} \sum_{i \in\left\{i: y_{i} \geq x_{i}^{\prime} \beta\right\}} \theta\left|y_{i}-x_{i}^{\prime} \beta\right| \\
& +\sum_{i \in\left\{i: y_{i}<x_{i}^{\prime} \beta\right\}}(1-\theta)\left|y_{i}-x_{i}^{\prime} \beta\right|,
\end{aligned}
$$

where $|z|$ is the absolute value of number $z$. 
When $\theta=0.5$, then the sum of absolute residuals is minimized (also referred to as median regression). With $\theta$ continuously increasing from 0 to 1 , we can trace the entire distribution of $y$, conditional on $x$ (Buchinsky, 1998). Quantile regression problem [2] was solved using the simplex (Barrodale and Roberts, 1973), interior point (Karmarkar, 1984), and smoothing algorithms (Madsen and Nielsen, 1993) in SAS software (version 9.2 of SAS for Windows; SAS Institute Inc. Cary, NC). Regression parameter confidence intervals are calculated using the rank method (Koenker and d'Orey, 1993). The regression coefficients can be interpreted as the partial derivative of the conditional quantile of $y$ with respect to the corresponding regressors $\partial \operatorname{Quant}_{\theta}\left(y_{i} \mid\right.$ $\left.x_{i}\right) / \partial x_{i, j}$. It is the marginal change in the $\theta$ th conditional quantile due to a marginal change in the $j$ th element of $x$ (Buchinsky, 1998).

The effect of dairy operation size, measured as number of cows (ncow) is estimated in the regression using a nonlinear continuous spline function (Greene, 2012). The function is set up as follows:

$$
\text { size effect }=\beta_{0}+\beta_{1} c_{0}+\beta_{2} c_{1}+\beta_{3} c_{2}+\beta_{4} c_{3},
$$

where $c_{i}=\max \left[\right.$ ncow $\left.-k_{i}, 0\right]$, and we have 4 categories $i \in\{1,2,3,4\}$, with $k_{0}=0, k_{1}=50, k_{2}=200$, and $k_{3}=$ 500 . Therefore the effects of size are measured as

$$
\begin{array}{ll}
\beta_{1}, & \text { whenever } n \text { cow }<k_{1} ; \\
\sum_{i=1}^{2} \beta_{i}, & \text { whenever } k_{1} \leq n \text { cow }<k_{2} ; \\
\sum_{i=1}^{3} \beta_{i}, & \text { whenever } k_{2} \leq n \text { cow }<k_{3} ; \\
\sum_{i=1}^{4} \beta_{i}, & \text { whenever ncow } \geq k_{3} .
\end{array}
$$

\section{Data and Data Procedures}

Data used in our empirical analysis are from the USDA 2005 ARMS phase III Dairy Costs and Returns Report. The ARMS endeavor is administered jointly by the USDA Economic Research Service and National Agricultural Statistics Service (NASS; MacDonald et al., 2007). The underlying survey is part of a larger data collection endeavor by the USDA and responses are obtained through a sequence of in-depth structured interviews with producers. The dairy survey is conducted approximately every $5 \mathrm{yr}$, but the 2010 survey does not include information on SCC. Dairy farms were selected from a list of farm operations maintained by NASS, following a stratified sample design, described below. Data available include cow inventories, milk production, management practices, technology use, farm input use and assets, as well as demographic informa- tion on the farm operator and operator's household. The survey also provides information on milk quality as measured by SCC. The survey targeted dairy operations in 24 states that account for more than $90 \%$ of national milk production and covered all major production areas (McBride and Greene, 2009). Survey data had a total of 1,814 observations.

Phase III of the survey for dairy farms asked whether milk produced in the operation was tested for SCC during 2005, and also the average SCC for milk tested during the year. It is important to note that although the higher annual SCC means higher monthly SCC in some months, it may mask variation over months. However, the annual average is the only measure reported in the survey. For the purposes of our analysis, we included only observations that had their milk tested for SCC during $2005(\mathrm{n}=1,790)$. We deleted observations that reported SCC over 1,000,000 cells/mL (13 observations), as these were deemed to produce milk that was not marketable and the level suggests an enterprise under severe disease stress. We also dropped observations with no response, "don't know," or missing values on variables relevant in our analysis (21.6\%), leaving a total of 1,374 observations.

The ARMS sample was developed from a complex survey design including stratification, clustering, dual frames, and unequal probability sampling (NRC, 2008). Available survey weights account for the survey design as well as survey nonresponse, and generate population estimates based on useable responses to represent dairy operations in the 24 states (McBride and Greene, 2009). As dropped observations may affect the representativeness of the sample, we compared the generated population from the original data set $(\mathrm{n}=1,814)$ with that arising after dropping observations $(\mathrm{n}=1,374)$. The generated population estimates for all relevant variables from the 2 data sets are very close, with an average difference of only $0.32 \%$; thus, dropping them is not likely to lead to any bias in the population based estimates.

Variables used are presented in Table 1, whereas summary data for the survey population estimates are presented in Table 2. The SCC level is the dependent variable $y$ in the regression. The survey mean for $\mathrm{SCC}$ is 258,000 cells $/ \mathrm{mL}$ across all dairy operations in the sample. Figure 1 shows that the data's SCC distribution is left skewed. Approximately $7.6 \%$ of farms violate a 400,000 cells $/ \mathrm{mL}$ limit. The number of farms that are not in compliance with the EU SCC standards in our data set (albeit, based on annual data) is close to the $7.8 \%$ obtained in Norman et al. (2011) for DHI herds tested from November 2009 through October 2010.

Among independent variables, dairy operation size (ncow) is categorized into 4 groups: less than 50 cows 
Table 1. Description of variables used in the analysis

\begin{tabular}{|c|c|}
\hline Variable & Explanation \\
\hline $\begin{array}{l}\text { SCC } \\
\text { ncow } \\
\text { c0 } \\
\text { c1 } \\
\text { c2 } \\
\text { c3 } \\
\text { Southeast } \\
\text { cowage } \\
\text { tmilked } \\
\text { offfarm } \\
\text { college } \\
\text { age } \\
\text { biosecurity } \\
\text { organic } \\
\text { facilage } \\
\text { opmprin }\end{array}$ & $\begin{array}{l}\text { "On average, what was the SCC of your milk?" }(1,000 \text { cells } / \mathrm{mL}) \\
\text { Number of cows (dairy cow inventory during } 2005) \\
\text { Dairy cow inventory during } 2005 \\
\text { c0 - } 50 \text { if ncow was } 50 \text { or more, } 0 \text { otherwise } \\
c 0-200 \text { if ncow was } 200 \text { or more, } 0 \text { otherwise } \\
\text { c0 - } 500 \text { if ncow was } 500 \text { or more, } 0 \text { otherwise } \\
1 \text { if operation located in Southeast (Tennessee, Kentucky, Florida, and Georgia), } 0 \text { otherwise } \\
\text { Average age of cows in the milking herd } \\
\text { Times per day herd was milked } \\
1 \text { if operator or spouse worked off-farm for wages or salary for at least } 26 \text { wk, } 0 \text { otherwise } \\
1 \text { if college degree or beyond, } 0 \text { otherwise } \\
\text { Operator age, in years } \\
1 \text { if this operation had guidelines to determine which visitors were allowed in animal areas, } 0 \text { otherwise } \\
1 \text { if the operation producing certified organic milk, } 0 \text { otherwise } \\
\text { Average facility or building age in years since last remodeled } \\
\text { The first principal component of } 3 \text { factors: Did this operation } \\
\text { 1. use regular scheduled veterinary services? } \\
\text { 2. keep individual cow production records? } \\
\text { 3. use an on-farm computer to manage dairy records? } \\
\text { The first principal component of } 2 \text { factors: did } \\
\text { 1. this operation use a holding pen with an udder washer? } \\
\text { 2. the milking units have automatic takeoffs? } \\
\text { The principal component analysis results of the questions: Does the buyer of your milk or your milk } \\
\text { cooperative require } \\
\text { 1. testing for extra water? } \\
\text { 2. testing for antibiotic residue? } \\
\text { 3. testing for pesticides or other residue? } \\
\text { 4. testing for PI (pasteurization incubation)? } \\
\text { 5. testing for SPC (standard plate count)? } \\
\text { 6. your cows to pass a test for tuberculosis? } \\
\text { 7. your cows or milk to be tested for other pathogens (such as Salmonella, Campylobacter, Listeria, } \\
\text { Escherichia coli)? } \\
\text { 8. your farm to follow a Hazard Analysis and Critical Control Point (HACCP) program or the } \\
\text { Performance-Based Dairy Farm Inspection System? } \\
\text { The analysis identified } 2 \text { important factors: Buyreq1, which was mainly accounted for by } 1,2,3,6,7, \text { and } \\
\text { 8; and Buyreq2, which was mainly accounted for by } 4 \text { and } 5\end{array}$ \\
\hline
\end{tabular}

Table 2. Summary data for variables ${ }^{1}$ used

\begin{tabular}{lc}
\hline Variable & Mean \\
\hline SCC $(\times 1,000$ cells $/ \mathrm{mL})$ & 258.399 \\
ncow & 153.160 \\
size1, <50 cows $(\%)$ & 31.4 \\
size2, 50-199 cows $(\%)$ & 54.5 \\
size3, 200-499 cows (\%) & 8.8 \\
size4, $>500$ cows (\%) & 5.3 \\
Southeast (1 or 0) & 0.042 \\
cowage (yr) & 4.646 \\
tmilked (times per day) & 2.076 \\
offfarm (1 or 0) & 0.264 \\
college (1 or 0) & 0.174 \\
age (yr) & 51.188 \\
biosecurity (1 or 0) & 0.263 \\
organic (1 or 0) & 0.016 \\
facilage (yr) & 23.937 \\
opmprin (PC) & -0.293 \\
facprin (PC) & -0.367 \\
buyreq1 (PC) & -0.066 \\
buyreq2 (PC) & -0.198 \\
\hline
\end{tabular}

${ }^{1}$ Descriptions of the variables are given in Table 1.

${ }^{2} \mathrm{PC}=$ principal component.

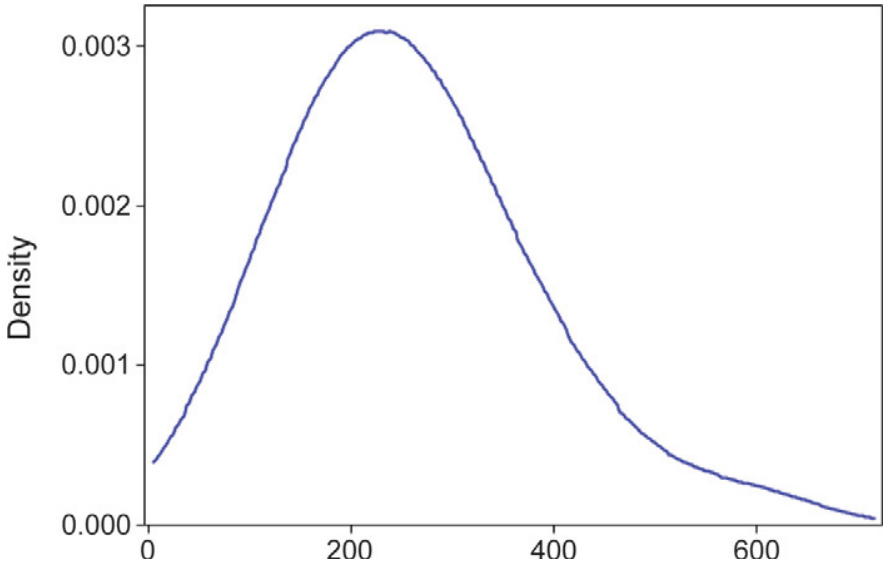

Figure 1. Kernel density of SCC (1,000 cells $/ \mathrm{mL})$ levels for farms in the USDA 2005 Agricultural Resource Management Survey (ARMS). Color version available in the online PDF. 
(size1), 50 to 199 cows (size2), 200 to 500 cows (size3), and over 500 cows (size 4 ) and specified as a nonlinear continuous spline function as specified in Equation 3, with $k_{i}$ as given previously.

Geography matters for SCC. Hot, humid weather is considered to increase SCC, as it favors the growth of mastitis-causing pathogens (Shearer and Bray, 1995; APHIS, 1999). We include location to capture this climate effect where the 1-0 variable Southeast takes value 1 whenever the operation is located in the Southeast. Tennessee, Kentucky, Florida, and Georgia are the only southeastern states included in the data set. Only $4.2 \%$ of surveyed dairy operations were located there. The data show that the average SCC level for Southeast dairy farms was 330,000 cells $/ \mathrm{mL}$, compared with 255,000 cells $/ \mathrm{mL}$ in other regions. In addition, $22 \%$ of Southeast dairy farms had SCC levels over 400,000 cells/ $\mathrm{mL}$, compared with only $5.3 \%$ of farms in other regions. Other specifications that used average temperature and relative humidity to replace Southeast produced similar regression parameters and results similar to those in the empirical analysis.

Younger cows tend to produce milk with lower SCC levels (Bradley and Green, 2005; Jones, 2009) and diligent culling protocols reduce SCC levels (Barkema et al., 1998). Therefore, we included a variable for average age of cows in the milking herd (cowage) to capture the age effect of the milking cows. The variable tmilked indicates how many times per day the herd was milked, as associations between frequency of milking and SCC have been identified (Kelly et al., 1998).

Offfarm is a 1-0 variable with value 1 whenever the operator or spouse worked off-farm for wages or a salary for at least $26 \mathrm{wk}$ in 2005 . Off-farm work is associated with less time available for on-farm operations, monitoring, and management, and so may lead to higher SCC levels. We include variables intended to capture any human capital-related effects. College is a 1-0 variable with value 1 whenever the operator had at least a college degree. Age denotes the farm operator's age, whereas the square of age is included to capture any trade-off between experience and physical decline. We also use a 1-0 indicator for overall attention to biosecurity, as this may suggest the managerial mindset required to protect quality milk. Biosecurity has value 1 whenever the operation had biosecurity guidelines to determine which visitors were allowed in animal areas; $26 \%$ of dairy operations had such guidelines. The 1-0 variable Organic takes value 1 whenever the operation produced certified organic milk during 2005. About $1.6 \%$ of dairy operations in the sample data produced certified organic milk during 2005.

Many features of the form of capital, equipment, and machinery assets, including housing, milking, and ma- nure management equipment, are associated with SCC values (Dufour et al., 2011). We hypothesized that older equipment was not as well designed for milk quality preservation, and that in any case it no longer served this purpose as well. We used average milking facility or building age in years since last remodeled (facilage) to represent the asset base capacity to protect milk quality. Regressions, including variables for floor type (e.g., partly slotted and solid concrete, among others) and manure handling (e.g., shallow pit, deep pit, and dry lot truck removal, among others), were also conducted. But neither of these variable sets displayed significant associations and they were omitted from further consideration.

The survey includes many variables indicating the dairy farms' practices and management. As we wished to parsimoniously account for a dairy operation's practice and management choices as well as for other characteristics in the regression analysis, we conducted a principal component analysis (PCA; see Jolliffe, 2002) on each of (a) dairy operation management measures, (b) operation facilities, and (c) buyer requirements so as to resolve the observed variables into a smaller number of principal components that would account for most of the variance. The eigenvalue-one criterion (Kaiser, 1960) and the scree test (Cattell, 1966) were used as criteria for determining the number of components. With the eigenvalue-one criterion, components with an eigenvalue greater than 1.00 are retained. With the scree test, the eigenvalue is plotted against the eigenvalue number. This typically forms a decreasing, concave plot as the vector's capacity to explain variation declines. Factors where the plot is flat are discarded.

Adherence to operation management practices, including record keeping, relates to improved SCC performance (Bartlett et al., 1992; Rodrigues et al., 2005). A PCA was conducted on dairy operation management, which includes three 1-0 response items, with "yes" coding to 1 . These were as follows: did this operation (a) use regular scheduled veterinary services; (b) keep individual cow production records; or (c) use an on-farm computer to manage dairy records? Based on both the eigenvalue-one (greater-than-one) criterion and the scree test, 1 component was retained and it accounted for approximately $57 \%$ of the total variance. All 3 items were found to load on the retained component (opmprin) with factor loading 0.4 or greater.

Specific capital outlays tied to milking practices may affect SCC. Studies suggest that use of automatic takeoff reduces SCC when monitored to prevent overmilking (Dufour et al., 2011), and udder hygiene practices also matter (Elmoslemany et al., 2010). To assess any role for these specific investments, a PCA was also con- 
ducted on a dairy operation's facilities, which included two 1-0 response items, with "yes" coding to 1 . These were as follows: did (a) this operation use a holding pen with an udder washer and (b) the milking units have automatic takeoffs? The component retained (facprin) accounted for approximately $61 \%$ of the total variance, where both items were found to load on this component with factor loading 0.4 or greater. Proper milking practices, udder hygiene, and good mastitis prevention and control can lead to lower standard plate count values (Oliver, 2009).

A PCA was conducted to develop a measure of the buyer requirements. The 8 questions are reported as 1 to 8 under buyreq in Table 1. Based on both the eigenvalue-one criterion and scree test, 2 components (buyreq1 and buyreq2) were retained, respectively accounting for 48 and $16 \%$ of total variance. Five items (items 1, 2, 3, 6, 7, and 8) were found to load on buyreq1, whereas 2 (items 4 and 5) loaded on buyreq2. Item 4 (pasteurization incubation) provides a measure of milk quality in addition to SCC. It is a test used to monitor the cleaning and sanitizing efficiency of milking equipment and udder preparation before milking. Item 5 (standard plate count) measures the number of bacteria in raw milk and is mandated by the US Grade "A" Pasteurized Milk Ordinance. Therefore, buyreq1 can be interpreted as the buyer food safety requirements, whereas buyreq2 can be interpreted as the buyer sanitary or quality requirements.

The standard errors of the survey population means were calculated using the delete-a-group jackknife method (Kott, 1998; NRC, 2008). The USDA/NASS provides 15 sets of replicate weights in the ARMS data, which are used in the jackknife estimates. However, as noted by the NRC (2008) and MacDonald and Wang (2011), jackknife procedures produce larger variance estimators than classical inference procedures do and, thus, are more conservative. The variance estimator can be highly variable in certain situations given the small number (15) of jackknife replicates. Therefore, in the analysis, we also looked at the general trend of estimations even if they were not significant at traditional levels of statistical significance (here, $\alpha=0.10$ ).

\section{RESULTS}

Table 3 reports the design-based (weighted) quantile regression results at the $0.05,0.25,0.50,0.75$, and 0.95 SCC distribution quantiles, as well as OLS estimates. All standard errors are computed using jackknife methods with the 15 replicate weights provided by NASS. Quantile regression curves are displayed in Figure 2. For each of the 19 coefficients, we plot the distinct quantile regression estimates, with $\theta$ ranging from 0.05 to 0.95 as the solid line. For each plot, the horizontal scale represents quantile, whereas the vertical scale in thousands represents the covariate effect on SCC. The shaded area depicts a $90 \%$ pointwise confidence band for the quantile regression estimates.

The OLS regression shows that presence in the Southeast, an increase each year in average herd age, and offfarm employment increased the mean SCC by 84,000 , 25,000 , and 20,000 cells/mL, respectively. The biosecurity, operations management, facilities investment, and buyer sanitary requirements variables (buyreq2) decreased mean SCC by $35,000,6,000,5,000$, and 10,000 cells $/ \mathrm{mL}$, respectively. Other variables, including herd size, organic farm status, operator age, level of formal education attained, and buyer food safety requirements (buyreq1) were not found to have significant effects according to OLS results and the more conservative approach to calculating standard errors.

By comparing OLS estimates and quantile results, we can see that OLS estimation missed some important aspects. In particular, the adverse effect of the operation's presence in the Southeast was not a factor for the operations with the lowest SCC (0.05 quartile). The effect of increasing SCC occurred in farms at or above the 0.25 quartile. Older cow herds (cowage) were associated with higher SCC levels for those operations with relatively low SCC (the bottom half of the distribution), but the age of the herd had little added effect at the upper ends of the herd SCC distribution. The imposition of biosecurity practices is most beneficial among herds with higher SCC levels. In contrast, buyer sanitary requirements (buyreq2) were associated with lower SCC levels among operations with low SCC levels. In summary, location in the Southeast and the age of the cow herd negatively affected SCC levels for operations that had relatively low SCC levels, whereas buyer sanitary requirements had a beneficial effect in reducing SCC for these operations. For operations that had high SCC levels, location in the Southeast was associated with higher levels of SCC, and biosecurity practices were associated with lower levels of SCC.

\section{DISCUSSION}

\section{Effects of Factors on SCC Levels}

Norman et al. (2011) used DHIA record-keeping data to find that large herds were generally less likely to breach SCC quality limits. For Wisconsin, Ingham et al. (2011) found no support for the claim that smaller farms have lower SCC. We found little support for size effects on SCC levels.

Farms located in the Southeast had higher SCC than those in other regions, and when cow herd age 
Table 3. Quantile regression estimates of effects of variables on farm milk SCC level ${ }^{1}$

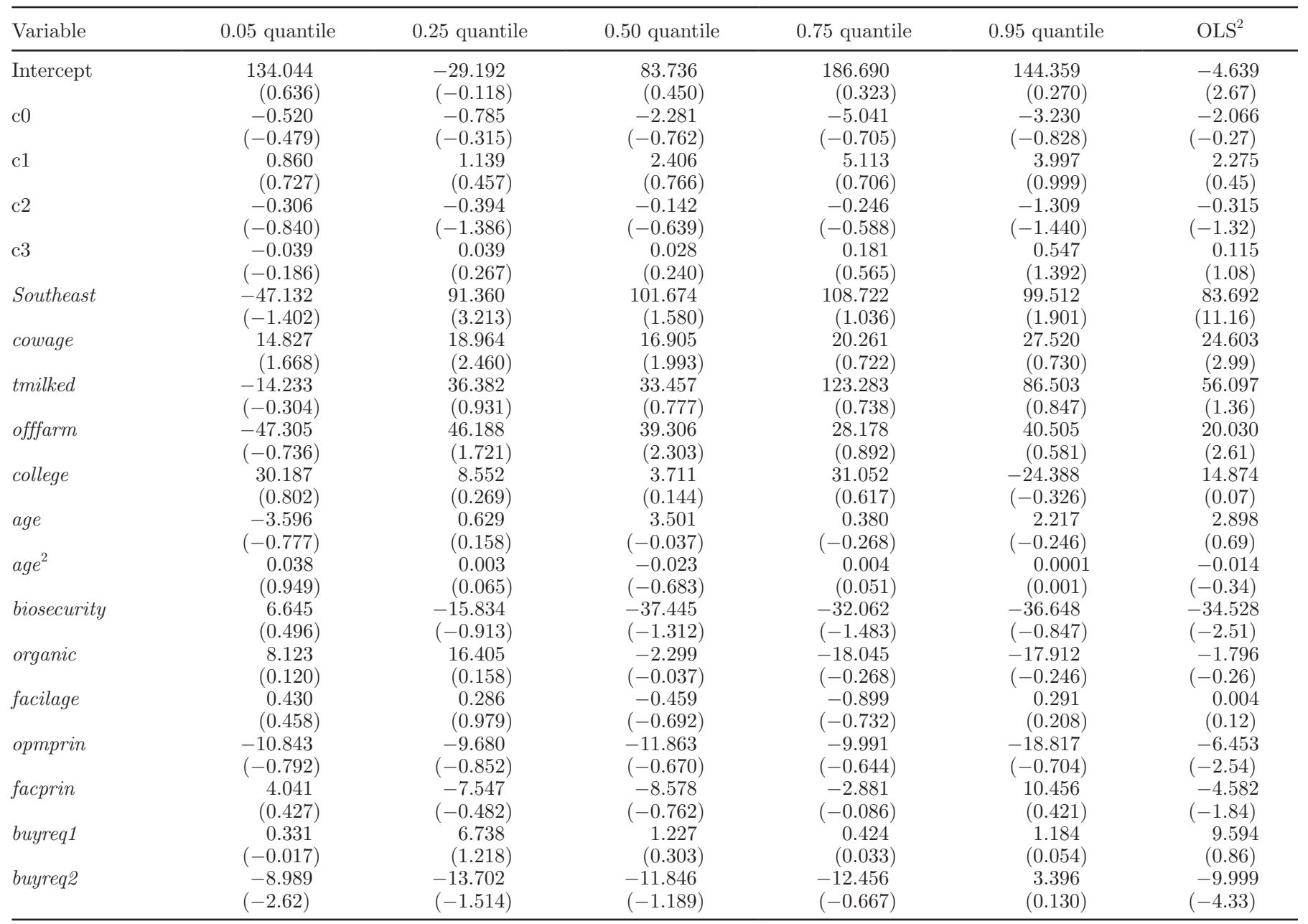

${ }^{1} t$-values are reported in parentheses. Descriptions of the variables are given in Table 1.

${ }^{2}$ Ordinary least squares.

increased, SCC levels also increased. Both findings are consistent with studies in the literature that indicate that younger cows and diligent culling tend to produce milk with lower SCC levels. Our results also suggest no association between milking frequency and SCC levels. The literature is inconclusive concerning the precise effect of milking procedures on SCC (Table 2 in Dufour et al., 2011).

Milk was typically of lower quality when a farmer or spouse worked more than half time off-farm. More offfarm work may distract farmers from focusing on herd management, which may negatively affect milk quality. Bartlett et al. (1992) found that use of hired labor was associated with higher SCC levels.

The biosecurity measure, regarding the restriction of access to animal areas, does correlate with lower SCC levels. We are not aware of other inquiries along this specific line, but do note that others have explored the matter more generally. For example, for herds in France from 1999 to 2001, Barnouin et al. (2004) found that when herdsmen live close to the cow barn, and also when they self-report as being specialized and meticulous, the herd SCC is lower.

Our results do not identify a statistically significant effect of organic practice on SCC levels. This is consistent with Sato et al. (2005), who found that the arithmetic mean of SCC on organic dairy farms was not statistically significantly different from that on conventional ones in Wisconsin. How organic farming might affect SCC performance is unclear. Only $1.6 \%$ of the operations in our sample were classified as organic. Pasture grazing is associated with high SCC values (Pomiès et al., 2000), and certification requirements leave US organic dairy producers with relatively limited choices when treating cows for bacterial diseases (Ruegg, 2009). In the event of mastitis, organic producers are likely to face greater losses than under conventional practices due to higher unit production costs (McBride and Greene, 2009). On 


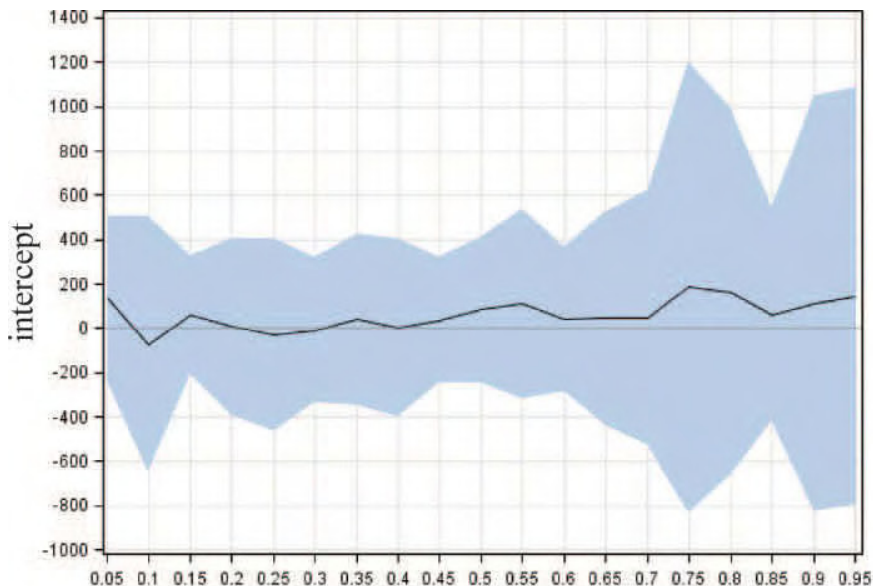

Quantile
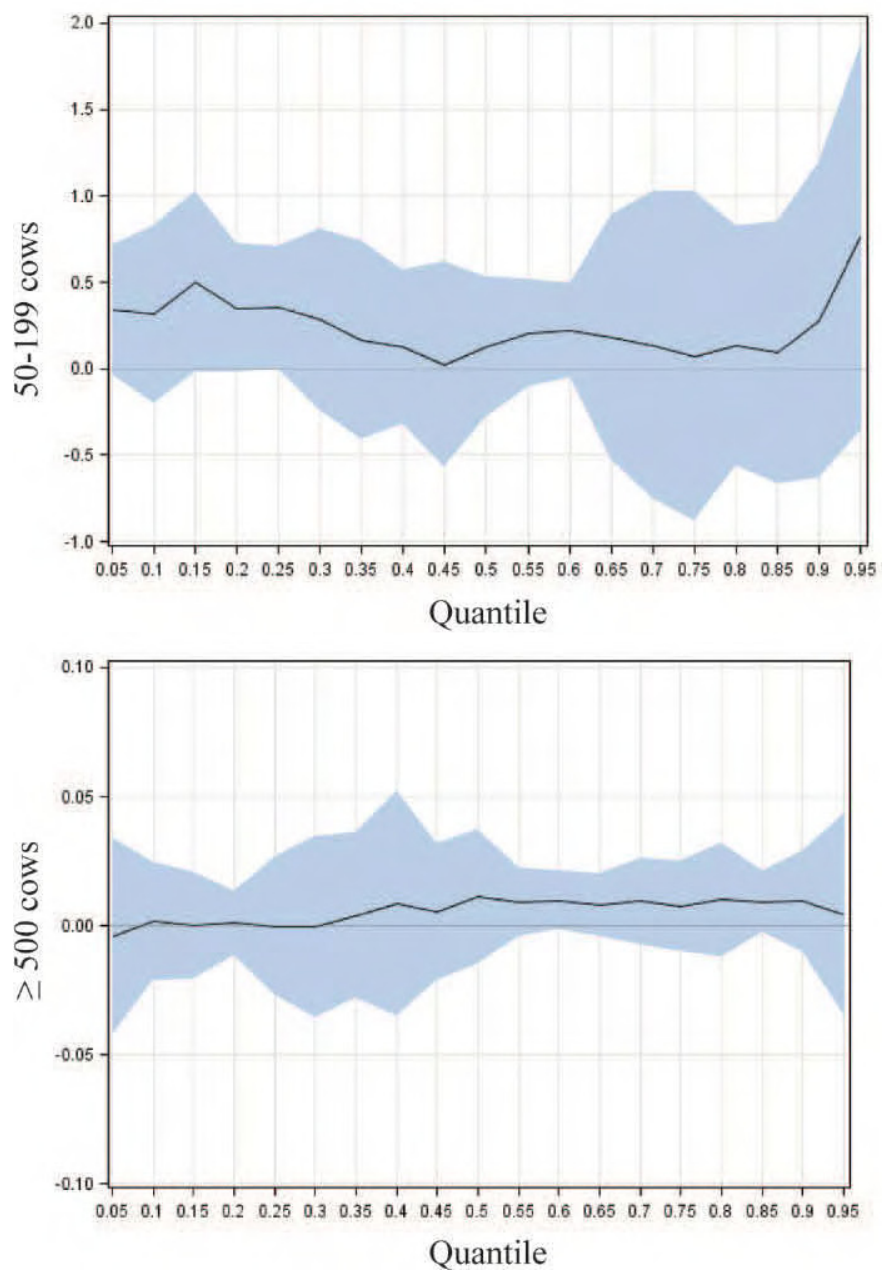

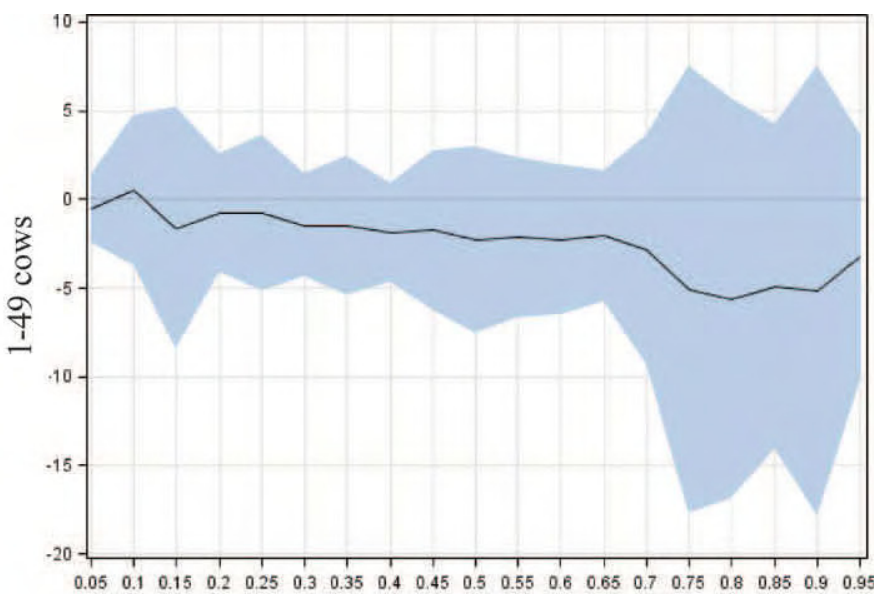

Quantile

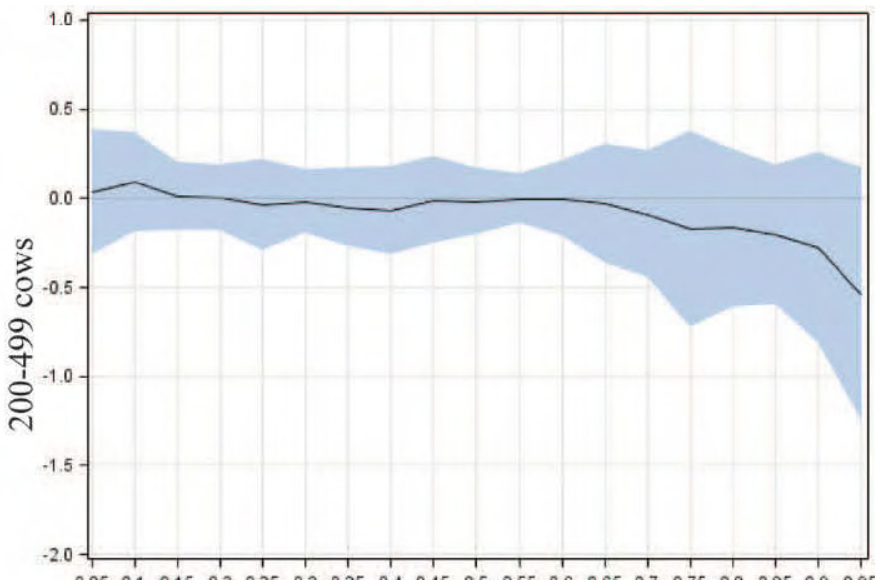

Quantile

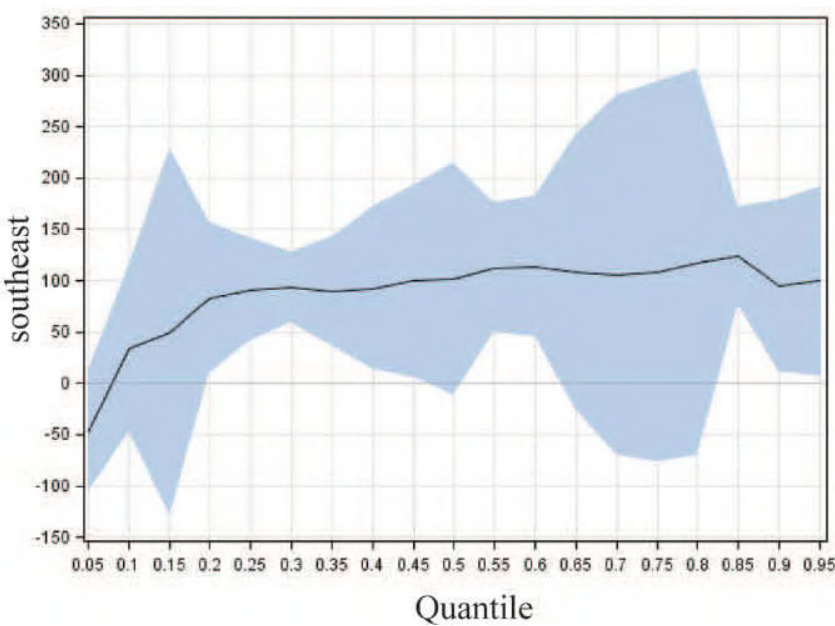

Figure 2. Quantile regression curves of effects of variables on farm SCC level. Southeast = Tennessee, Kentucky, Florida, and Georgia; cowage $=$ average age of cows in the milking herd; tmilked $=$ how many times per day the herd was milked; offfarm = a 1-0 variable with value 1 whenever the operator or spouse worked off-farm for wages or a salary for at least $26 \mathrm{wk}$; college = a 1-0 variable with value 1 whenever the operator had at least a college degree; biosecurity = a 1-0 variable with value 1 whenever the operation had biosecurity guidelines to determine which visitors were allowed in animal areas; age = the farm operator's age; age $e^{2}$ is included to capture any trade-off between experience and physical decline; organic $=$ a $1-0$ variable with value 1 whenever the operation produced certified organic milk during 2005; facilage $=$ average milking facility or building age in years since last remodeled; opmprin and facprin $=$ the retained components (described in Table 1) with factor loading 0.4 or greater; buyreq 1 and buyreq2 = retained buyer requirements components (described in Table 1 ), accounting for 48 and $16 \%$ of total variance, respectively. Color version available in the online PDF. 

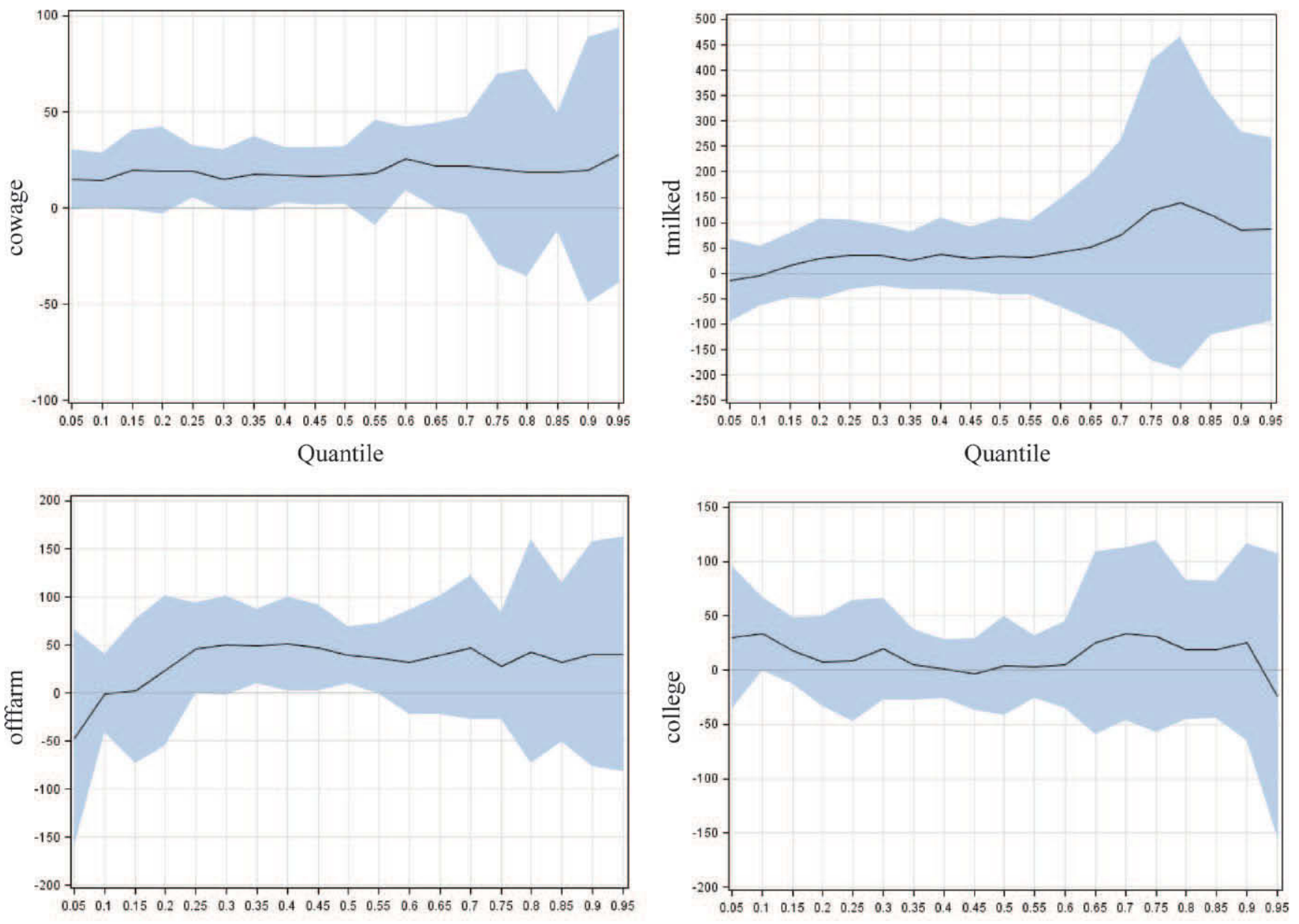

Quantile
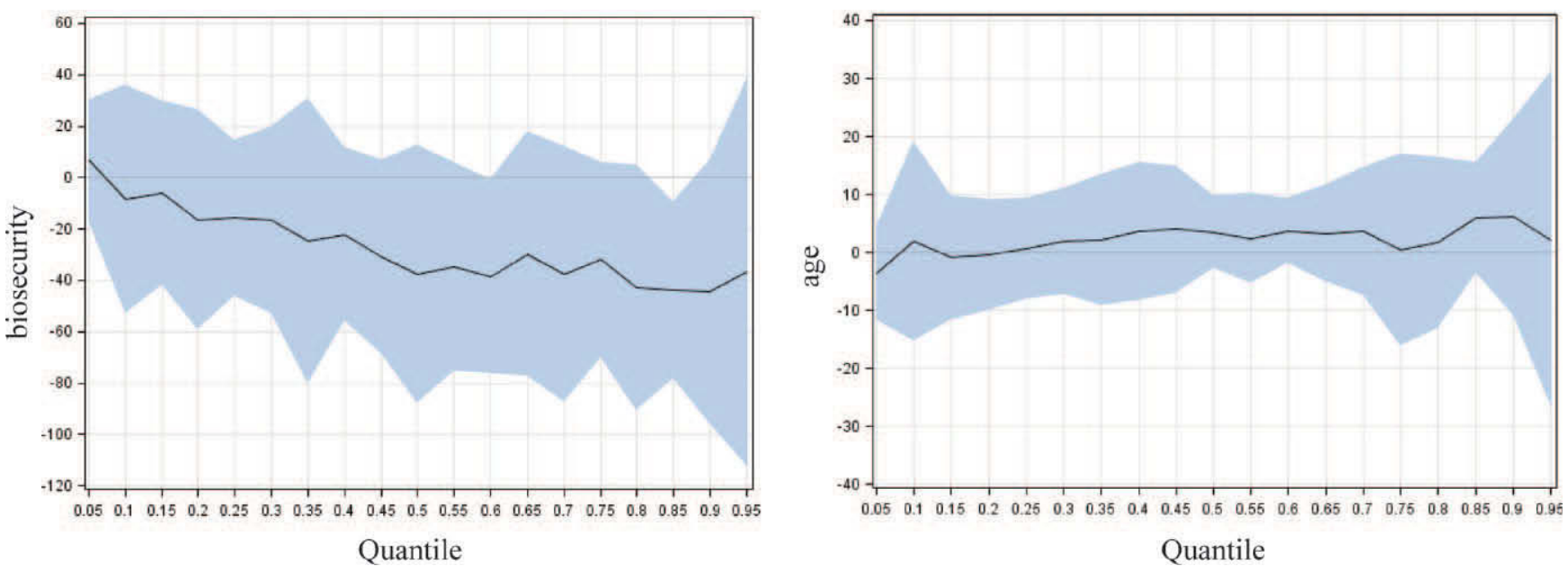

Figure 2 (Continued). Quantile regression curves of effects of variables on farm SCC level. Southeast = Tennessee, Kentucky, Florida, and Georgia; cowage = average age of cows in the milking herd; tmilked $=$ how many times per day the herd was milked; offfarm $=$ a $1-0$ variable with value 1 whenever the operator or spouse worked off-farm for wages or a salary for at least 26 wk; college = a 1-0 variable with value 1 whenever the operator had at least a college degree; biosecurity = a 1-0 variable with value 1 whenever the operation had biosecurity guidelines to determine which visitors were allowed in animal areas; age = the farm operator's age; $a g e^{2}$ is included to capture any trade-off between experience and physical decline; organic = a 1-0 variable with value 1 whenever the operation produced certified organic milk during 2005; facilage = average milking facility or building age in years since last remodeled; opmprin and facprin = the retained components (described in Table 1 ) with factor loading 0.4 or greater; buyreq1 and buyreq2 = retained buyer requirements components (described in Table 1 ), accounting for 48 and $16 \%$ of total variance, respectively. Color version available in the online PDF. 

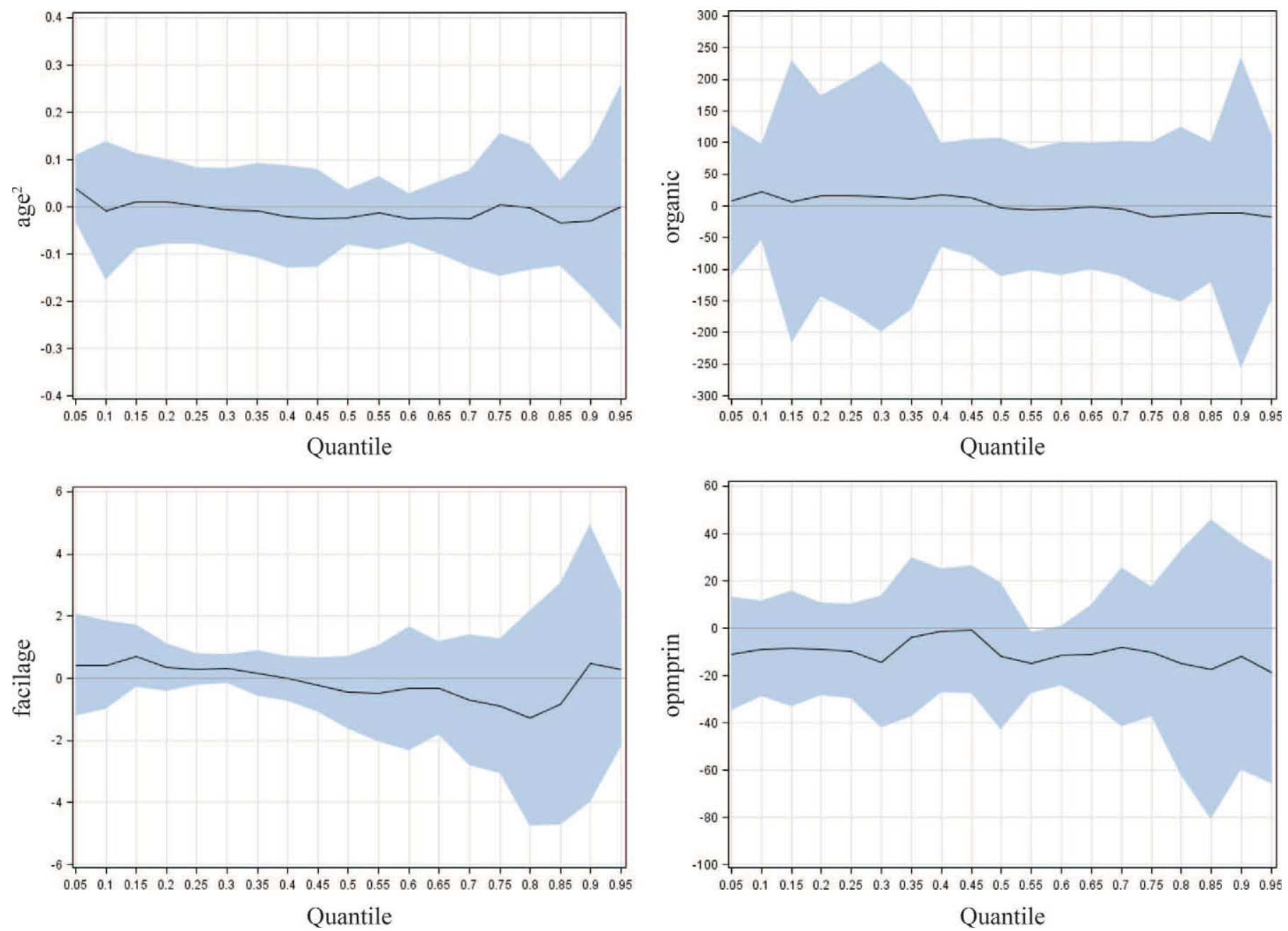

Figure 2 (Continued). Quantile regression curves of effects of variables on farm SCC level. Southeast = Tennessee, Kentucky, Florida, and Georgia; cowage = average age of cows in the milking herd; tmilked = how many times per day the herd was milked; offfarm = a 1-0 variable with value 1 whenever the operator or spouse worked off-farm for wages or a salary for at least 26 wk; college $=$ a 1-0 variable with value 1 whenever the operator had at least a college degree; biosecurity = a 1-0 variable with value 1 whenever the operation had biosecurity guidelines to determine which visitors were allowed in animal areas; age = the farm operator's age; age is included to capture any trade-off between experience and physical decline; organic = a 1-0 variable with value 1 whenever the operation produced certified organic milk during 2005; facilage $=$ average milking facility or building age in years since last remodeled; opmprin and facprin = the retained components (described in Table 1 ) with factor loading 0.4 or greater; buyreq1 and buyreq 2 = retained buyer requirements components (described in Table 1 ), accounting for 48 and $16 \%$ of total variance, respectively. Color version available in the online PDF.

the other hand, organic price premiums may promote greater efforts to manage quality.

We are not aware of any other work relating buyer requirements to SCC performance. Buyer food safety requirements (buyreq1) that included testing for extra water, antibiotic residues, pesticide and other residues, and pathogens, and following a Hazard Analysis and Critical Control Point (HACCP) program had no effect on SCC levels. However, the testing included in the second measure (buyreq2) did decrease SCC. Practices that are closely related to udder hygiene and health, such as testing for pasteurization incubation and stan- dard plate count, are more likely to have a direct bearing on SCC.

\section{Effects of Change in SCC Standard}

Many of the concerns about strengthening US national cell count standards regard the impact on particular sets of producers. Size change and geographic shift along with some other farm characteristics have been identified as important components of structural change in US dairy farming (MacDonald et al., 2007; Mosheim and Knox Lovell, 2009). Therefore, we focused 

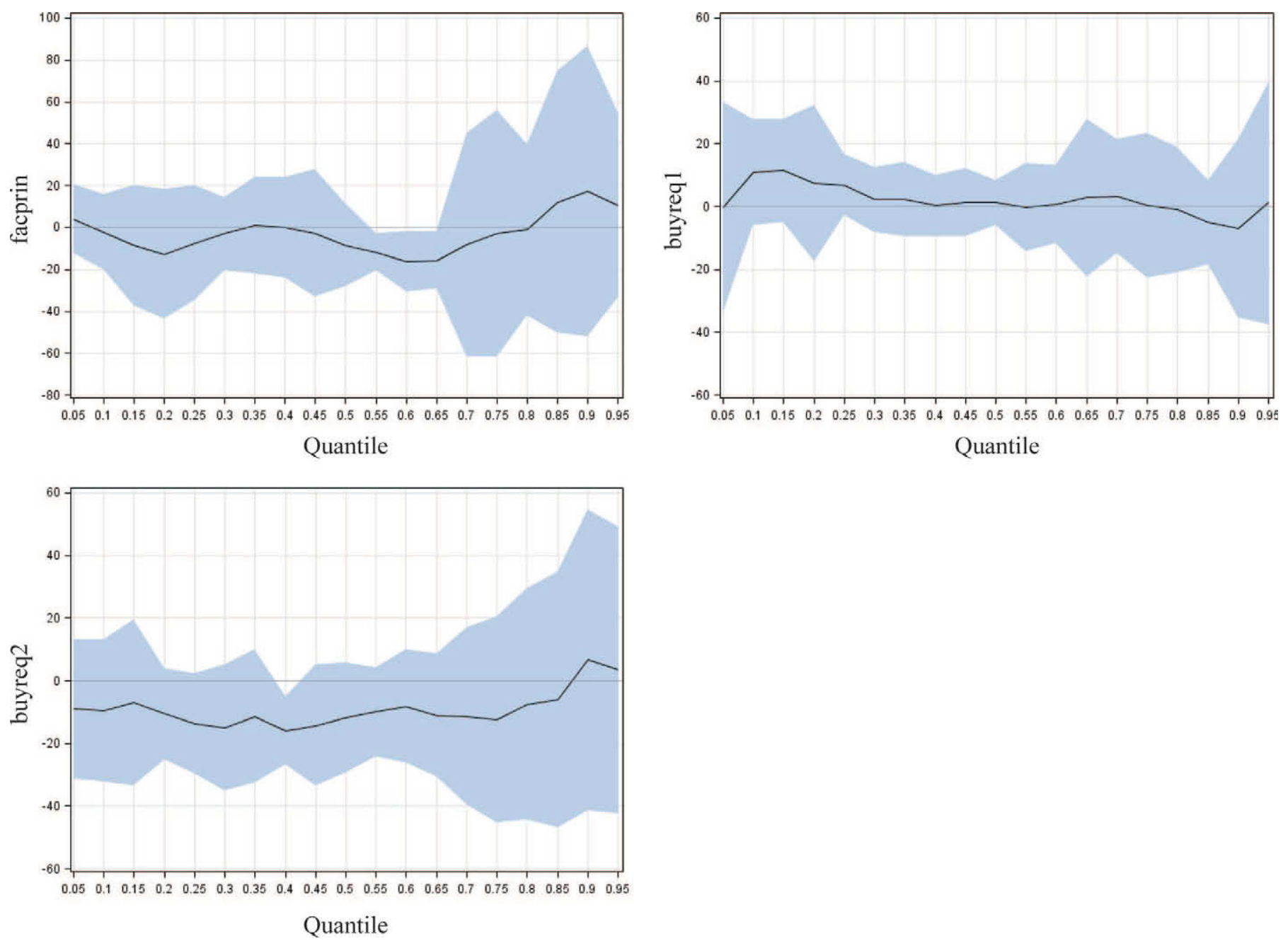

Figure 2 (Continued). Quantile regression curves of effects of variables on farm SCC level. Southeast = Tennessee, Kentucky, Florida, and Georgia; cowage $=$ average age of cows in the milking herd; tmilked $=$ how many times per day the herd was milked; offfarm $=$ a $1-0$ variable with value 1 whenever the operator or spouse worked off-farm for wages or a salary for at least 26 wk; college = a 1-0 variable with value 1 whenever the operator had at least a college degree; biosecurity = a 1-0 variable with value 1 whenever the operation had biosecurity guidelines to determine which visitors were allowed in animal areas; age = the farm operator's age; $a g e^{2}$ is included to capture any trade-off between experience and physical decline; organic = a 1-0 variable with value 1 whenever the operation produced certified organic milk during 2005; facilage $=$ average milking facility or building age in years since last remodeled; opmprin and facprin = the retained components (described in Table 1) with factor loading 0.4 or greater; buyreq 1 and buyreq $2=$ retained buyer requirements components (described in Table 1 ), accounting for 48 and $16 \%$ of total variance, respectively. Color version available in the online PDF.

on several variables for herd size, operation characteristics, and operator characteristics to better understand the differences and nature of adjustment that may be required.

Current SCC standard requires that SCC should not exceed 750,000 cells $/ \mathrm{mL}$. We conducted an analysis that compared the character of surveyed farms that did and did not attain an SCC limit of no more than 400,000 cells $/ \mathrm{mL}$ annual average. This is not the 3-mo geometric mean criterion as specified in the EU regulation, but survey data did not allow us to arrive at a better approximation. In the survey data, 13 out of 1,814 farms reported annual average SCC over 750,000 cells $/ \mathrm{mL}$, and none of these remained after our screens, as outlined in Data and Data Procedures.

Given that a farm attained the 750,000 cells $/ \mathrm{mL}$ limit, Table 4 provides survey means for farms that did and did not attain the 400,000 cells/mL limit. It also provides $t$-tests between farms that did and did not attain the 400,000 cells/mL limit across variables that reflect the nature of the operation. These variables include herd size, total hours that the operator spent on farm as a share of total labor hours (hour ratio), operator's age (age) and operation's legal status (sole or family proprietorship, taking a value of 1 if yes and 0 otherwise). Included, too, are the operator's expec- 
Table 4. Survey variable means for farms under the current SCC limit and a lower SCC limit ${ }^{1,2}$

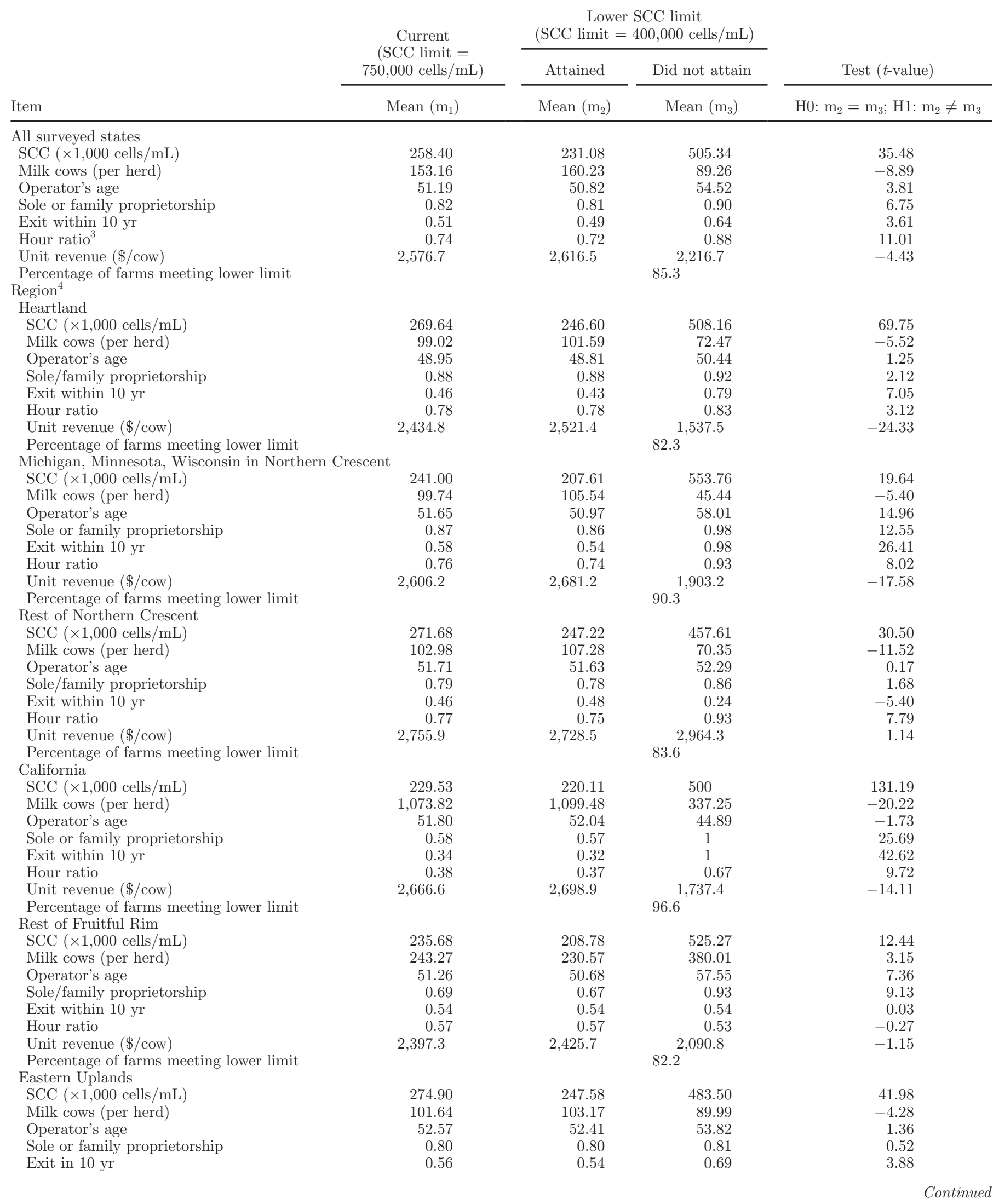


Table 4 (Continued). Survey variable means for farms under the current SCC limit and a lower SCC limit ${ }^{1,2}$

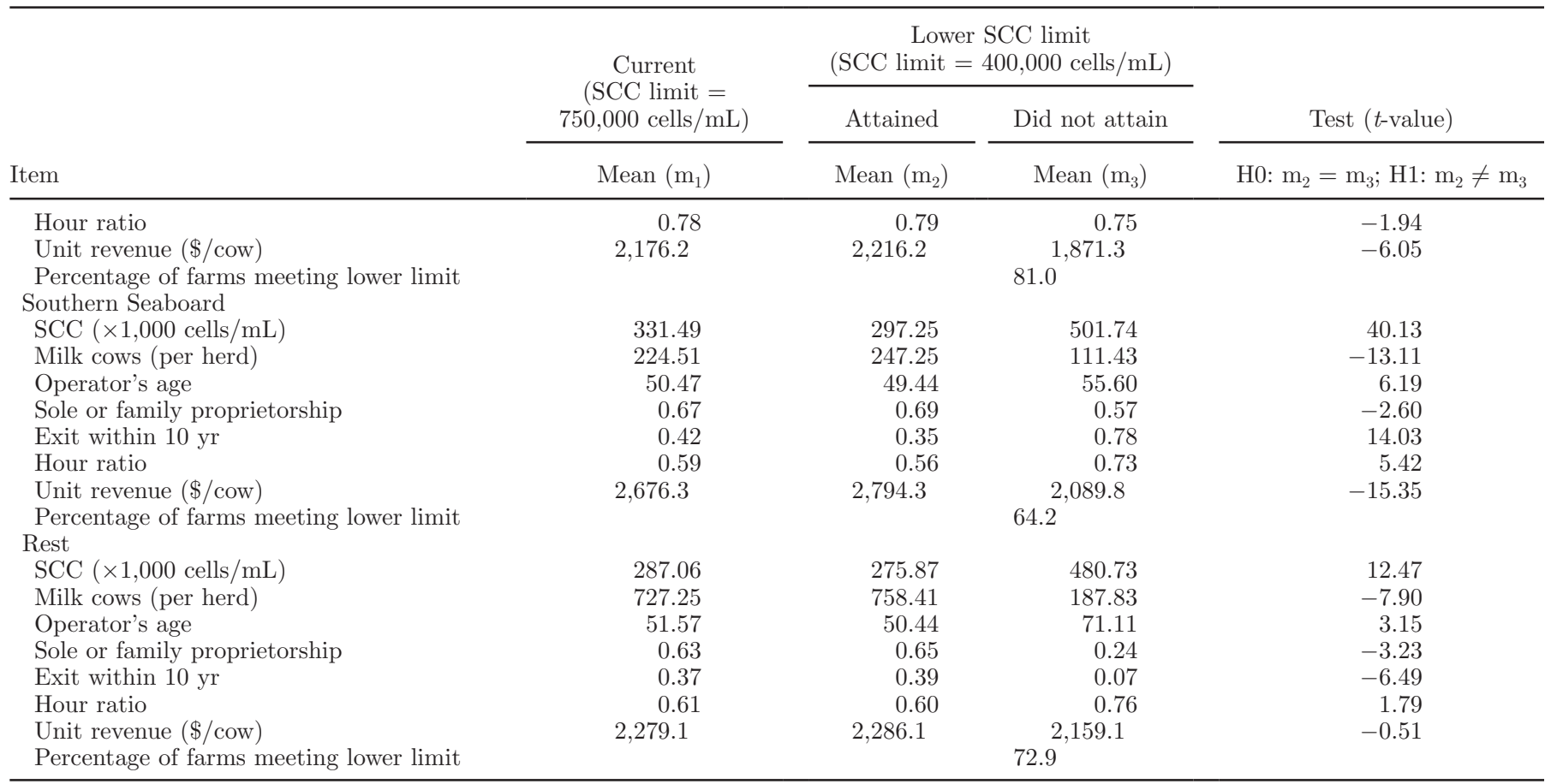

${ }^{1}$ Statistical test is conducted using jackknife method.

${ }^{2}$ Survey weights are used to generate population.

${ }^{3}$ Hour ratio is the total hours that the operator spent on farm as a share of total labor hours.

${ }^{4}$ Location is categorized into 8 groups based on Economic Research Service (ERS, Washington, DC) farm resource regions: Heartland states in the survey are Illinois, Indiana, Iowa, Kentucky, Minnesota, Missouri, and Ohio; Northern Crescent states in the survey are Maine, Michigan, Minnesota, New York, Ohio, Pennsylvania, Vermont, and Wisconsin, but we separate out Minnesota, Wisconsin, and Michigan to make an additional group; Fruitful Rim states are Arizona, California, Idaho, Oregon, and Washington, but we separate out California to make an additional group; Eastern Uplands states are Georgia, Kentucky, Missouri, Ohio, Pennsylvania, Tennessee, and Virginia; Southern Seaboard states are Georgia, Texas, and Virginia; and the rest of the regions are grouped as Rest. The ERS farm resource regions (USDA, 2000) are clustered by counties instead of states. Therefore, a state can be segregated into different regions, and Agricultural Resource Management Survey (ARMS) data indicate the appropriate region for each observation.

tation regarding operation discontinuance 10 yr later (taking a value of 1 if not expected to continue and 0 otherwise) and revenue per cow (unit revenue). Revenue is measured as gross value generated from milk sales and the value is divided by number of cows to generate unit revenue.

The hypothesis tests were to determine whether the survey variable means among farms that attained the limit and farms that did not were equal. Our results suggest that a lower SCC limit would provide more management challenges to farms with fewer cows, lower revenue per cow, older operators, sole or family proprietorships using mainly proprietor labor, and those intending to exit within $10 \mathrm{yr}$. Effects at the region level of disaggregation are generally consistent with those at the national level. Notice that although herd size effects were not identified in regression analysis, they did arise here. This is because regression analysis controls for investments and management practices whose prevalence varies with herd size. No such controls are in place in Table 4.
To address the concern arising during NCIMS deliberations in May 2011 that the tighter standards would render southern dairy farms unviable, we examined survey responses regarding the attainment of a 400,000 cells/mL SCC limit across different states using survey weights to generate the population. Figure 3 shows the percentage of farms in each of the 24 states included in the data set that attained the more stringent limit. The figure suggests that many farms in southeastern states, such as Florida, Georgia, and Tennessee, would have difficulty in meeting a lower SCC limit.

\section{CONCLUSIONS}

Using USDA ARMS data, we identified associations between farm characteristics and milk SCC, although we noted that the reported annual average SCC could mask large variation in data observed over a shorter period. Results should be interpreted with this in mind. Operator on-farm presence, biosecurity protocols, lower herd age, milking equipment that one would expect to 


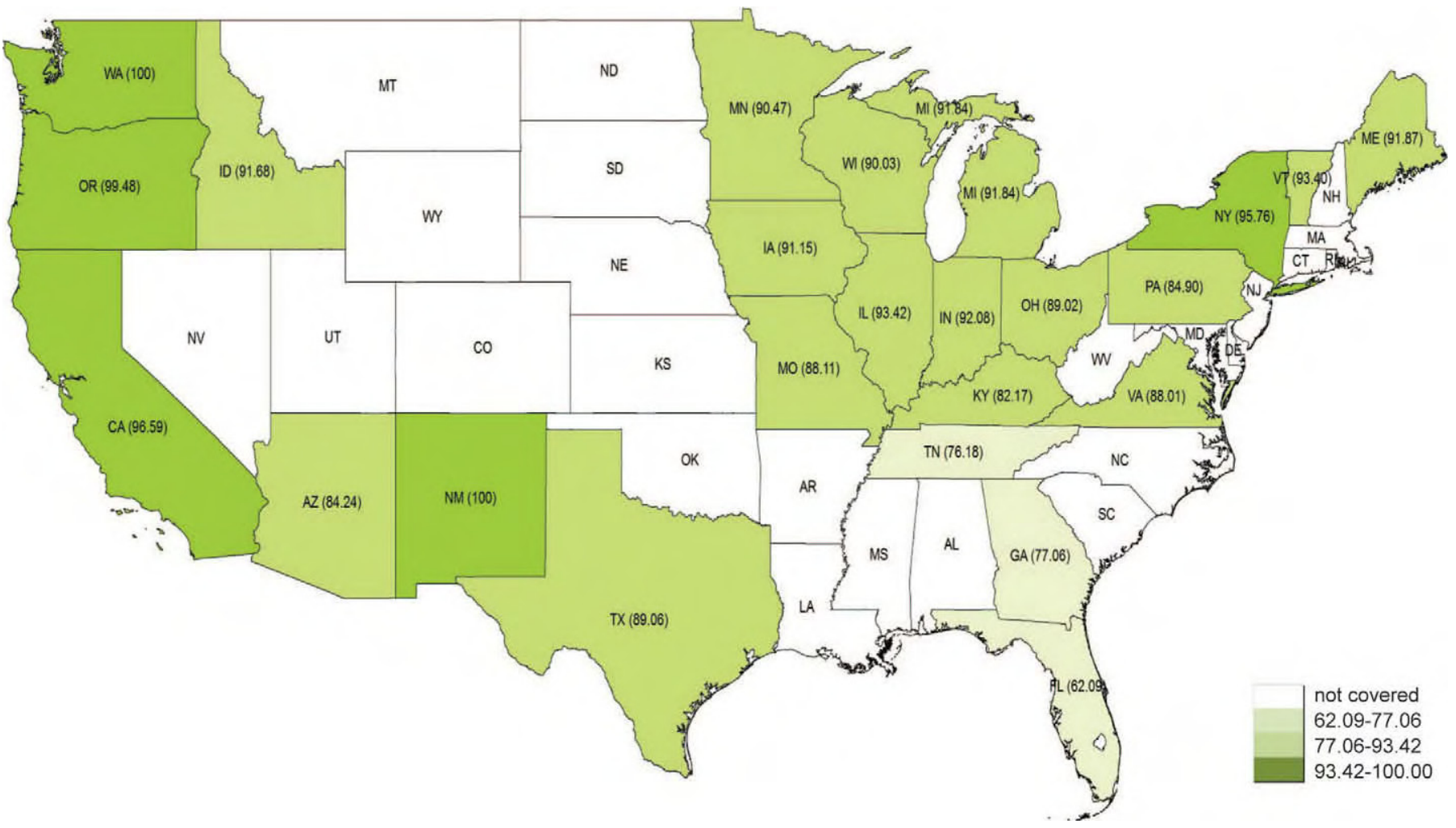

Figure 3. Percentage of farms that met the SCC limit of 400,000 cells/mL, by state. Color version available in the online PDF.

improve sanitation, and buyer sanitary and quality requirements that test for related quality measures were all associated with lower SCC levels. However, these covariate associations were not consistent across all levels of SCC. An inference is that producers delivering different milk qualities may need to emphasize different actions to reduce SCC. Comparisons between farms that did and those that did not attain a more stringent SCC limit suggest that larger farms, with their attendant features, are best placed to attain a more stringent SCC limit. On average, those that did not attain the more demanding standard in the 2005 survey had older operators and a larger fraction expressed intentions to exit within 10 yr. For these operators, a change in standards would hasten the retirement outcome. Finally, and consistent with popular concerns, our findings do suggest that herds in southeastern states would face the greatest challenges in meeting a 400,000 cells/mL standard.

\section{ACKNOWLEDGMENTS}

The Economic Research Service, US Department of Agriculture (Washington, DC) provided access to the data, as well as partial financial support for the analysis. The authors thank Richard Volpe and Timo- thy Park (both of the Economic Research Service) for comments and suggestions.

\section{REFERENCES}

APHIS (Animal and Plant Health Inspection Service). 1999. Monitoring U.S. milk quality using bulk tank somatic cell counts, 1997. Info sheet. Accessed June 22, 2012. http://www.aphis.usda. gov/animal_health/nahms/dairy/downloads/dairy_monitoring/ BTSCC_97infosheet.pdf.

Barbano, D. M., Y. Ma, and M. V. Santos. 2006. Influence of raw milk quality on fluid milk shelf life. J. Dairy Sci. 89(E. Suppl. 1):E15-E19.

Barkema, H. W., Y. H. Schukken, T. J. G. M. Lam, M. L. Beiboer, H. Wilmink, G. Benedictus, and A. Brand. 1998. Incidence of clinical mastitis in dairy herds grouped in three categories by bulk milk somatic cell counts. J. Dairy Sci. 81:411-419.

Barnouin, J., M. Chassagne, S. Bazin, and D. Boichard. 2004. Management practices from questionnaire surveys in herds with very low somatic cell score through a national mastitis program in France. J. Dairy Sci. 87:3989-3999.

Barrodale, I., and F. D. K. Roberts. 1973. An improved algorithm for discrete $l_{1}$ linear approximation. SIAM J. Numer. Anal. 10:839848.

Bartlett, P. C., G. Y. Miller, S. E. Lance, and L. E. Heider. 1992. Environmental and managerial determinants of somatic-cell counts and clinical mastitis incidence in Ohio dairy herds. Prev. Vet. Med. 14:195-207.

Bradley, A., and M. Green. 2005. Use and interpretation of somatic cell count data in dairy cows. In Practice 27:310-315.

Buchinsky, M. 1998. Recent advances in quantile regression models: A practical guideline for empirical research. J. Hum. Resour. $33: 88-126$. 
Burggraff, J. 2010. EU enforces restrictions on somatic cell counts. Ag Weekly Online: Twin Falls, Idaho. Accessed June 22, 2012. http://www.agweekly.com/articles/2010/05/25/commodities/ dairy/dairy67.txt.

Caswell, J. A., and C. F. Bach. 2007. Food safety standards in rich and poor countries. Pages 281-304 in Ethics. Hunger and Globalization: In Search of Appropriate Policies. P. Pinstrup-Andersen and P. Sandøe, ed. Springer, New York, NY.

Cattell, R. B. 1966. The scree test for the number of factors. Multivariate Behav. Res. 1:245-276.

Dickrell, J. 2011. 400,000 somatic cell count proposal fails. Accessed June 22, 2012. http://www.agweb.com/topproducer/news/news. aspx? ArticleId $=303692$.

Dufour, S., A. Fréchette, H. W. Barkema, A. Mussell, and D. T. Scholl. 2011. Invited review: Effect of udder health management practices on herd somatic cell count. J. Dairy Sci. 94:563-579.

Elmoslemany, A. M., G. P. Keefe, I. R. Dohoo, J. J. Wichtel, H. Stryhn, and R. T. Dingwell. 2010. The association between bulk tank milk analysis for raw milk quality and on-farm management practices. Prev. Vet. Med. 95:32-40.

Gaafar, H. M. A., M. I. Basiuoni, M. F. E. Ali, A. A. Shitta, and A. S. E. Shamas. 2010. Effect of zinc methionine supplementation on somatic cell count in milk and mastitis in Friesian cows. Archiva Zootechnica 13:36-46.

Greene, W. 2012. Econometric Analysis. Prentice Hall, Upper Saddle River, NJ.

Hand, K. J., M. A. Godkin, and D. F. Kelton. 2012. Bulk milk somatic cell penalties in herds enrolled in Dairy Herd Improvement programs. J. Dairy Sci. 95:240-242.

Ingham, S. C., Y. Hu, and C. Ané. 2011. Comparison of bulk-tank standard plate count and somatic cell count for Wisconsin dairy farms in three size categories. J. Dairy Sci. 94:4237-4241.

Jesse, E. V., and W. D. Dobson. 2012. U.S. dairy trade situation and outlook: 2012. Babcock Institute Discussion Paper No. 2012-1. University of Wisconsin, Madison.

Jolliffe, I. 2002. Principal Component Analysis. Springer Series in Statistics. 2nd ed. Springer, New York, NY.

Jones, G. 2009. DHI somatic cell count program guidelines. Virginia Cooperative Extension, Publication 404-228. Accessed June 22, 2012. http://pubs.ext.vt.edu/404/404-228/404-228.html.

Kaiser, H. F. 1960. The application of electronic computers to factor analysis. Educ. Psychol. Meas. 20:141-151.

Karmarkar, N. 1984. A new polynomial-time algorithm for linear programming. Combinatorica 4:373-395.

Kelly, A. L., S. Reid, P. Joyce, W. J. Meaney, and J. Foley. 1998. Effect of decreased milking frequency of cows in late lactation on milk somatic cell count, polymorphonuclear leucocyte numbers, composition and proteolytic activity. J. Dairy Res. 65:365-373.

Koenker, R., and G. Bassett Jr. 1978. Regression quantiles. Econometrica 46:33-50.

Koenker, R., and V. d'Orey. 1993. A remark on computing regression quantiles. Appl. Stat. 43:410-414.

Kott, P. S. 1998. Using the delete-a-group jackknife variance estimator in NASS surveys. NASS Research Report, RD-98-01 (Revised July 2001). National Agricultural Statistics Service (NASS), Washington, DC.

MacDonald, J., E. O'Donoghue, W. McBride, R. Nehring, C. Sandretto, and R. Mosheim. 2007. Profits, costs, and the changing structure of dairy farming. Economic Research Report No. 47. United States Dept. of Agriculture, Economic Research Service, Washington, DC

MacDonald, J. M., and S.-L. Wang. 2011. Foregoing sub-therapeutic antibiotics: The impact on broiler grow-out operations. Appl. Econ. Perspect. Pol. 33:79-98.
Madsen, K., and H. B. Nielsen. 1993. A finite smoothing algorithm for linear L1 estimation. SIAM J. Optim. 3:223-235.

McBride, W. D., and C. Greene. 2009. Costs of organic milk production on U.S. dairy farms. Appl. Econ. Perspect. Pol. 31:793-813.

Mosheim, R., and C. A. Knox Lovell. 2009. Scale economies and inefficiency of US dairy farms. Am. J. Agric. Econ. 91:777-794.

NRC. 2008. Understanding American agriculture: Challenges for the Agricultural Resource Management Survey. The National Academies Press, Washington, DC.

Nightingale, C., K. Dhuyvetter, R. Mitchell, and Y. Schukken. 2008. Influence of variable milk quality premiums on observed milk quality. J. Dairy Sci. 91:1236-1244.

Norman, H. D., J. E. Lombard, J. R. Wright, C. A. Kopral, J. M. Rodriguez, and R. H. Miller. 2011. Consequences of alternative standards for bulk tank somatic cell count of dairy herds in the United States. J. Dairy Sci. 94:6243-6256.

Norman, H. D., R. H. Miller, and J. R. Wright. 2000. Herd and state means for somatic cell count from Dairy Herd Improvement. J. Dairy Sci. 83:2782-2788.

Oliver, S. P. 2009. How milk quality is assessed. DAIReXNET. Accessed June 22, 2012. http://www.extension.org/pages/21197/ how-milk-quality-is-assessed.

Pomiès, D., P. Gasqui, J. Bony, J.-B. Coulon, and J. Barnouin. 2000. Effect of turning out dairy cows to pasture on milk somatic cell count. Ann. Zootech. 49:39-44.

Rodrigues, A. C., D. C. Caraviello, and P. L. Ruegg. 2005. Management of Wisconsin dairy herds enrolled in milk quality teams. J. Dairy Sci. 88:2660-2671.

Ruegg, P. L. 2009. Management of mastitis on organic and conventional dairy farms. J. Anim. Sci. 87:43-55.

Salsberg, E., A. H. Meek, and S. W. Martin. 1984. Somatic cell counts: Associated factors and relationship to production. Can. J. Comp. Med. 48:251-257.

Sato, K., P. C. Bartlett, R. J. Erskine, and J. B. Kaneene. 2005. A comparison of production and management between Wisconsin organic and conventional dairy herds. Livest. Prod. Sci. 93:105-115.

Schutz, M. M. 2011. Changes in standards for milk quality and how they will affect your clients. Pages 79-87 in Proc. 20th Annu. TriState Dairy Nutr. Conf., Fort Wayne, IN. Ohio State University, Columbus.

Shearer, J. K., and D. R. Bray. 1995. Maintaining udder health and milk quality during periods of hot weather. Dairy Food Environ. Sanit. 15:368-370.

Smith, K., and J. Hogan. 2001. The world of mastitis. Page 1-12 in Proc. 2nd Int. Symp. Mastitis Milk Quality, Vancouver, Canada. National Mastitis Council, Madison WI.

Stephenson, M., and D. Barbano. 2010. Marketing quality milk. Accessed June 22, 2012. http://www.extension.org/pages/11323/ marketing-quality-milk.

USDA (US Department of Agriculture). 2000. Farm Resources Regions. Agricultural Information Bulletin Number 760. Accessed June 22, 2012. http://www.ers.usda.gov/publications/aib760/aib760.pdf.

USDA (US Department of Agriculture). 2011. Report of the Dairy Industry Advisory Committee Submitted to the Secretary of Agriculture. Accessed June 22, 2012. http://www.fsa.usda.gov/Internet/FSA_File/diac_final_rpt_0302.pdf.

US Department of Health and Human Services. 2009. Grade "A" Pasteurized Milk Ordinance, 2009 Revision. Accessed June 22, 2012. http://www.fda.gov/downloads/Food/FoodSafety/Product-SpecificInformation/MilkSafety/NationalConferenceonInterstateMilkShipmentsNCIMSModelDocuments/UCM209789.pdf. 